\title{
FORMATION OF POST-FIRE WATER-REPELLENT LAYERS IN MONTERREY PINE (Pinus radiata D. DON) PLANTATIONS IN SOUTH-CENTRAL CHILE
}

\author{
P. Garcia-Chevesich ${ }^{1,2^{*}}$, R. Pizarro ${ }^{3}$, C.L. Stropki ${ }^{4}$, P. Ramirez de Arellano ${ }^{5}$, P.F. \\ Ffolliott $^{6}$, L.F. DeBano ${ }^{6}$, D.G. Neary ${ }^{7}$, and D.C. Snack ${ }^{1}$ \\ ${ }^{1}$ University of Arizona, Department of Agricultural and Biosystems Engineering, 1177 E, Fourth \\ Street. Shantz Bldg \#38, Room 403, Tucson, AZ 85721, USA, Phone: 1-510-621-1753. \\ ${ }^{2}$ Universidad Santo Tomás, Facultad de Recursos Naturales, Ejercito 146, Santiago, Chile, Phone: \\ 56-2-362-4795; ${ }^{3}$ Universidad de Talca, Facultad de Ciencias Forestales, 2 Norte 685, Talca, \\ Chile, Phone: 56-71-200442; ${ }^{4}$ SWCA Environmental Consultants, 647 Jefferson Street North \\ East, Albuquerque, New México 87109, USA, Phone: 1-800-828-8499; ${ }^{5}$ Bioforest S. A. Camino \\ Coronel Km, 15, Concepción, Chile, Phone: 56-41-2728800; ${ }^{6}$ School of Natural Resources and \\ the Environment, The University of Arizona, Biological Sciences East, Tucson, AZ 85721, USA, \\ Phone: 1-520-621-7255; ${ }^{7}$ US Forest Service. Rocky Mountain Research Station. 240 West \\ Prospect, Fort Collins, CO 80526, USA. Phone: 1-970-498-1100. \\ *Corresponding author: pablog@email.arizona.edu
}

\begin{abstract}
A wildfire burned about 15,000 ha of Monterrey Pine (Pinus radiata D. Don) plantations near Yungay, Chile, in January of 2007. Post-fire water repellency (hydrophobicity) was measured using the water-drop-penetration-time (WDPT) method at depths of 0,5 , and $10 \mathrm{~mm}$ from the soil surface. These measurements were collected on burned sites of both young (4-years old) and old (11-years old) plantations having both sand- and clay-rich soils. For purpose of comparison, water repellency was also measured one year after the wildfire on four unburned sites representing the same soil types and plantation ages as those occurring on the burned sites. The statistical analyses indicated that water repellency was present only on old stands, being located on the soil surface (clay soils) or as a layer $10 \mathrm{~mm}$ deeper or below (sandy soils). However, a water repellent layer was found on young stands growing on sandy soils, five millimeters below the surface, assumed to be formed when a wildfire burned the area before the new plantation was established.
\end{abstract}

Keywords: Soil hydrophobicity, fire effects, wetting behavior.

\section{INTRODUCTION}

Water repellency, or hydrophobicity, is a physical property of soils that can be altered by fire. If a soil absorbs water slower than under normal conditions, it can indicate the presence of water repellency (DeBano, 1981). Water repellent soils have been studied by many researchers and land managers because of their potential negative impacts on the hydrologic cycle, especially on infiltration processes (DeBano, 2003). Soil water repellency is created as a result of the accumulation of certain types of organic compounds that have not been decomposed into humus (Doerr and Cerda, 2005). These substances can be 
produced during the metabolism and decomposition by plants and microbes (Doerr et al., 2000) or by exposing the accumulations of organic plant-materials on a soil surface to high temperatures (Doerr et al., 1998; DeBano, 2000a; Dekker and Ristema, 2000); the latter process was the case in this study.

Earlier studies have focused on the effects of $P$. radiata on the hydrologic cycle in Chile (Huber et al., 2008), although little is known about the consequences of post-fire water repellency on the hydrology of these commercially important plantations. According to the Corporación Nacional Forestal (2007), close to 5,200 wildfires impact over 52,000 ha of introduced and native forests in Chile every year, resulting in millions of dollars lost to investors and additional fire-fighting and post-fire rehabilitation costs. Fire research in the country, however, has focused largely on its effects on flora, fauna, and atmosphere conditions, paying little attention to its effects on soil resources (Doerr and Cerda, 2005).

The general phenomenon of water repellency has been studied on Chilean soils. Cuevas (2006) determined the soil water repellency in three volcanic soils from southern Chile, in combinations with two vegetation types (forest and prairie), also estimating the buffer capacity by using a hydrophilic compound in the soils. The author concluded that the main cause for water repellency was the type of organic matter (i. e., vegetation type). Also, he concluded that soils with similar pedogenetic characteristics showed different levels of hydrophobicity for the same vegetation type. Additionally, the buffer capacity of soils depended of the amount of organic matter, and its interaction with the mineral soil particles.

Ellies et al. (2005) assessed the wetting capacity of two soil types (Hapludands and Palehumults) under grassland and forest in southern Chile, respectively, by measuring contact angles on soil matrix and aggregate samples. The authors determined greater hydrophobic potentials on Hapludands. Additionally, they predicted that aggregate stability should decrease with time, due to the loss of organic matter and a decrease in wetting resistance, being such effect stronger on Hapludands. Besides, interesting results were found, such as (1) the wetting resistance of the soil matrix samples was less than that of the single layers of aggregates, (2) the wetting resistance of aggregates generally increased from the exterior to their centre, (3) the increase was strongest in the topsoil under grassland (4) smaller aggregates under both grassland and forest showed a greater hydrophobicity than larger ones (5) organic matter content increased towards the aggregate interiors, especially in the fine aggregates, and (6) aggregates with greater water repellency were more stable to dry and wet sieving, especially under forest. The authors concluded that intensive management decreases wetting resistance and makes the soil less stable.

Despite the numerous studies discussed above, none of them explicitly evaluated fire as a factor that can cause the formation of water repellent soil layers. However, a wildfire that burned over Monterrey pine plantations located $30 \mathrm{~km}$ northeast of Yungay, Chile, in January of 2007, which gave a unique opportunity for investigating the formation of post-fire water repellent layers in Chilean soils. Results of this study are reported in this paper.

\section{MATERIAL AND METHODS}

The wildfire burned roughly 15,000 hectares over a five-day period. Unfortunately, general fire characteristics 
such as flame length and duration were not documented during the wildfire. However, it is known that the wildfire lasted for one week, burning commercial plantations at different fire severities.

The burned area was located on a volcanic-depositional valley situated 180 $\mathrm{m}$ above sea level with gentle slopes (less than 5\%) (Paskoff, 1996). Temperate climate with three-to-five dry months in the summer season occurs in the region. Though annual precipitation exceeds $1,000 \mathrm{~mm}$, the seasonal precipitation for the area varies widely (Romero, 1985).

Four study sites on sand- and clay-rich soils with a comparatively young (4years-old) and old (11-years-old) plantations on each of soil site were established in the burned area. Parenthetically, the youngest stand on sandy soils was established after an 11year-old plantation was destroyed by an earlier wildfire in 2002. Water repellency was also evaluated on four comparable unburned sites, representing the same soil types and plantation ages, to determine whether water repellent soils also occurred on these sites. If not present on the unburned sites, the authors assumed that water repellency on burned sites would be attributed to the fire. Thirty sample points, $15 \mathrm{~m}$ apart in random directions, were located on approximately 0.5-ha on each of the study sites. These sample points were cleared of organic matter which was accumulated on the soil, to expose the mineral soil surface and to determine the occurrence and degree of water repellency. These measurements were taken at the soil surface and depths of 5 and $10 \mathrm{~mm}$.

Three days after the cessation of the wildfire, the measurements were carried out. The water-drop-penetration-time method (WDPT) (Letey et al., 2000; DeBano et al., 1998; Wallis et al., 1991) was used to evaluate the degree of water repellency. This method consists of placing a drop of distilled water on the mineral soil surface, documenting the time it takes for the drop to be absorbed into the soil. The classification system established by the National Wildfire Coordinating Group in the United States (Clark, 2001) was applied to determine the degree of water repellency as follows:

- Null or slight water repellency - the water drop is absorbed in less than 10 seconds.

- Moderate water repellency - the water drop takes between 10 and 40 seconds to be absorbed.

- Severe water repellency - the water drop takes more than 40 seconds to be absorbed.

A Chi-square analysis was used to determine significant differences among soil depths, soil types, and stand ages. An alpha level of 0.10 was established for the statistical analysis.

\section{RESULTS}

The level of water repellency varied widely among the study sites. No water repellency was found on the unburned sites, phenomenon also documented in similar studies focused on water repellency of Monterrey pine plantations (Scott and Van Wyk, 1990). However, significant differences in the degree of water repellency on the burned sites occurred among the three variables analyzed, that is, soil depth, soil types, and stand age (Figure 1).

The water repellent layer formed beneath the older plantation on sandy soils was thicker than the one documented beneath the older plantation on clay soils, starting at the surface and reaching 10 $\mathrm{mm}$ in depth. Water repellency beneath the older plantation on clay soils was represented slim (between one and two 


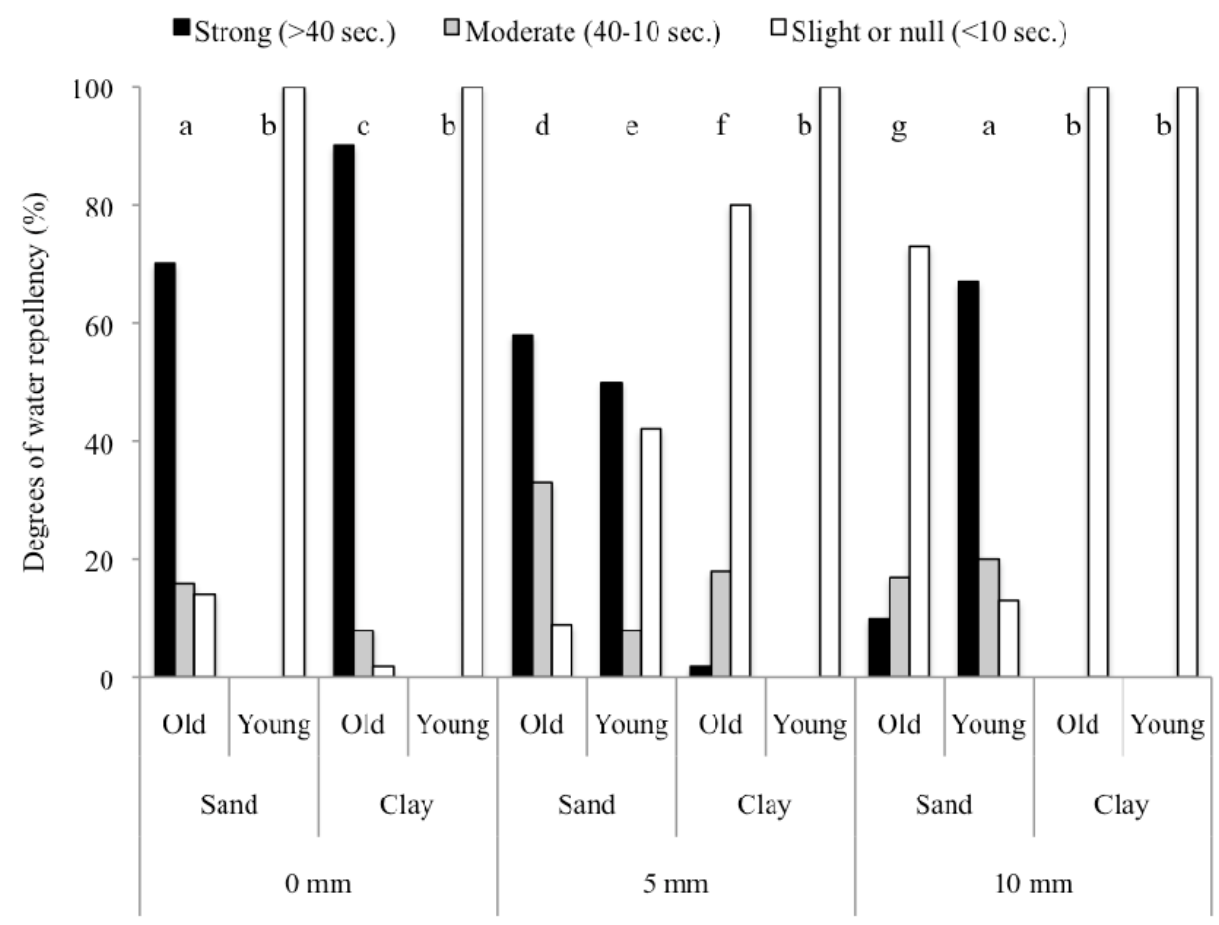

Figure 1. Post-fire water repellency in the soil (\%) relative to the depth of measurement, soil type, and age of the plantation sampled, measured using the Water Drop Penetration Time (WDPT) method. Proportions within the graph followed by the same letter are not significantly different at the 0.10 level, evaluated using a Chi-square analysis.

millimeters), but difficult-to-break layer, located on top of the mineral soil surface. On the other side, no water repellency was found on clay soils where young trees were growing. However, a thick and deep water repellent layer (absent within the first couple of millimeters from the soil surface) was detected beneath the younger plantation on the sandy soil site.

\section{DISCUSSION}

The absence of water repellency on unburned sites suggests that the water repellency measured at the burned sites was induced by the wildfire.
Having a thick $(10+\mathrm{mm})$ water repellent layer from the sand-rich soil surface is a common phenomena. In fact, similar results were obtained from a study on sandy soils in South Africa where a wildfire burned a Monterrey pine plantation (Scott and Van Wyk, 1990) and created a thick (up-to-150mm) post-fire water repellent layer. However, these findings differ from some other studies done on sandy soils within the United States and Australia (Gilmour, 1968; DeBano et al., 1970; DeBano, 1981; Stropki et al., 2005) in which the resulting post-fire hydrophobic layer was situated only a few millimeters below the sandrich soil surface. 
Heat produced during combustion in these soils often results in the migration of hydrophobic substances toward the larger pores to produce a thicker water repellent layer (DeBano, 1981; Dekker and Ristema, 1994). One explanation for the thick hydrophobic layers beginning at the soil surface is that there is a sufficient amount of heat produced by combustion at the soil and litter surface to create steep temperature gradients which can move the volatilized hydrophobic substances downward where they condense in the underlying cooler soil layers. As the fire severity decreases, this migration gradually decreases in distance until the extinction of the fire, when the hydrophobic compounds stopped their migration. Large quantities of organic matter could explain the thick water repellent layer observed. Fuelmanagement policies in Chile consisting on constant fire suppression, resulting in large accumulations of fuels from pine needles, also other management activities include pruning and thinning of the timber, but not removal of the slash caused from the management.

A fine superficial post-fire water repellent layer on clay-rich soils was also documented by McGhie and Posner (1980) in their study made in Australia. Heat from the fire in the present study was unable to transport the water repellent substances into the mineral soil, mostly because of the smaller pore size of the fine-textured soils, resulting in the hydrophobic layer forming on the soil surface (Bond, 1969).

Post-fire water repellency was absent beneath the younger plantation on the clay-rich soil site, as indicated previously. One explanation of this could be attributed to the immaturity of this plantation. Water repellent soils can be found under most coniferous trees, however this site may have not had time to develop the thick litter cover necessary for this development (Benavides-Solorio and MacDonald, 2001; Cuevas, 2006; Ellies et al., 2005). These results are also in agreement with Australian studies of post-fire water repellency beneath young Monterrey pine stands (John, 1978).

The presence of a thick buried water repellent layer suggest that such hydrophobic conditions might have been formed after a wildfire occurred in 2002, meaning that water repellency might have lasted for over five years. Similar results were reported by Scott (1997) in his study of a 5-year-old Monterrey pine plantation on sandy South African soils following clearcutting. Only a few studies have documented the duration of post-fire water repellent layers (DeBano, 2000b; Stropki et al., 2005; Erickson and White 2008). According to Campbell et al. (1977), water repellency can last up to three years after severe wildfires in Arizonan ponderosa pine (Pinus ponderosa) forests. Huffman et al. (2001) reported a persistence of two years for post-fire water repellency in the same type of forests in Colorado. A six-year persistence of post-fire water repellency, however, was documented by Dyrness (1976) on soils beneath lodgepole pine (Pinus contorta) forests in Oregon.

Those results suggest the incorporation of post-fire mitigation activities within Chilean policies, focused on the destruction of the water repellent layer, if any, to minimize erosion and maximize soil water infiltration (Leighton-Boyce et al., 2007; Neary 2009). Such activities could consist simply of the mechanical disaggregation by scarification of the first few centimeters of the mineral soil surface or deeper ripping (King, 1981; Robichaud et al., 2000) or increasing soil pH (Karnok et al., 1993). However, some land managers use wetting agents such as polyacryl-amide (PAM), a synthetic, high molecular weight organic polymer, to increase the wettability of the 
hydrophobic soil layer and improve infiltration into the soil (Letey et al., 1962; Wohlgemuth and Robichaud, 2007; Neary, 2009). Additionally, preventive pre-fire activities such as avoiding the accumulation of large amounts of organic matter are as effective as the ones mentioned above (Chan, 1992). Water repellency occurs naturally in forest ecosystems, but wildfire certainly aggravates it (DeBano et al., 1998). Furthermore, soil texture might play an important role on post-fire mitigation activities, depending on the type of method to be used.

\section{CONCLUSIONS}

The presence of fire-induced water repellency has been documented for the first time on Chilean soils. Significant differences in the degree of water repellency were found for the three variables considered (soil depth, soil type, and stand age). As expected, the texture of the soil influenced the thickness of the post-fire water repellent layers formed beneath the two plantations with the thicker layer occurring on coarser textured soils. Both sites, however, showed a water repellent layer positioned at the surface of the mineral soil. No water repellency was found beneath the younger plantation on clay soils, probably because of the lack of a deep litter layer. At the same time, a thick $(>5 \mathrm{~mm})$ water repellent layer was found beneath the younger plantation on the sandy soils. Though the reasons of this phenomenon are unknown, it was assumed that such layer could have formed during an earlier wildfire event.

\section{ACKNOWLEDGEMENTS}

The authors of this study honestly thank the cooperation of Forestal Arauco, the owner of the study sites. The invaluable help of Beatriz Barría, Gonzalo Muñoz, Manuel Muñoz, and Sergio Sepulveda is also appreciated. The senior author sincerely thanks Shaina Schwartz and Guillermo Garcia-Mendoza for their contributions in editing this paper.

\section{REFERENCES}

Benavides-Solori, J., MacDonald, L. 2001. Post-fire runoff and erosion from simulated rainfall on small plots, Colorado Front Range. Hydrol. Process. 15, 2931-2952

Bond, R.D. 1969. The occurrence of waterrepellent soils in Australia. In: L. F. DeBano, J. Letey (eds). Water-repellent soils. University of California, Riverside. May 6-10, 1968. Proceedings. Pp. 11-6.

Campbell, R.E., Baker Jr., M.B., Ffolliott, P. F., Larson, F.R., Avery, C.C. 1977. Wildfire effects on a ponderosa pine ecosystem: an Arizona case study. Rocky Mountain Forest and Range Experiment Station, Fort Collins, CO. U.S.D.A. Forest Service Research Paper RM191, $12 \mathrm{p}$.

Chan, K.Y. 1992. Development of seasonal water repellency under direct drilling. Soil Sci. Soc. Am. Pro. 5, 326-329.

Clark, B. 2001. Soil, water, and watersheds. In 'Fire effects guide.' (Eds Fire Use Working Team) pp. 93-109. (National Wildfire Coordinating Group. National Interagency Fire Center: Boise, ID) [http://www.nweg.gov], visited on 05/01/2008.

Corporación Nacional Forestal. 2007. Ocurrencia y daño de los incendios forestales. Cita electrónica visitada en agosto de 2007. [http://www.conaf.cl], visited on 08/08/2007. 
Cuevas, J. 2006. Efectos de la materia orgánica y el manejo sobre la hidrofobicidad de suelos volcánicos. R.C. Suelo Nut. Veg. 6(2), 13-27.

DeBano, L.F. 1981. Water Repellent Soils: A State-of-the Art. USDA Forest Service, General Technical Report PSW-46.

DeBano, L.F. 2000a. Water repellency in soils: a historical overview. J. Hydrol. 231-232, 4-32.

DeBano, L.F. 2000b. The role of fire and soil heating on water repellency in wildland environments: a review. J. Hydrol. 231-232, 195206.

DeBano, L.F. 2003. The role of fire and soil heating on water repellency In: C. J. Ritsema, L. W. Dekker (eds). Soil water repellency: Occurrence, consequences, and amelioration. Elsevier Science B. V. Amsterdam, The Netherlands, pp. 193-202.

DeBano, L.F., Mann, L.D., Hamilton, D.A 1970. Translocation of hydrophobic substances into soil by burning organic litter. Soil Sci. Soc. Am. Pro. 34, 130-133.

DeBano, L.F., Neary, D.G., Ffolliott, P.F. 1998. Fire's effects on ecosystems. John Wiley \&Sons, New York, NY. 333 p.

Dekker, L.W., Ritsema, C.J. 1994. How water moves in a water repellent sandy soil- 1 . Potential and actual water repellency. Water Resour. Res. 30(9), 2507-2517.

Dekker, L.W. Ritsema, C.J. 2000. Wetting patterns and moisture variability in water repellent Dutch soils. J. Hydrol. 231-232, 148164.

Doerr, S.H., Shakesby, R.A., Walsh, R.P.D. 2000. Soil water repellency, its characteristics, causes and hydro-geomorphological consequences. Earth-Sci. Rev. 51, 33-65.

Doerr, S.H., Cerda, A. 2005. Fire effects on soil system functioning: new insights and future challenges. Int. J. Wildland Fire 14, 339-342.

Doerr, S.H., Shakesby, R.A., Walsh, R.P.D. 1998. Spatial variability of soil water repellency in fire-prone eucalyptus and pine forests, Portugal. Soil Sci. 163, 313-323.
Dyrness, C.T. 1976. Effects of wildfire on soil wettability in the High Cascades of Oregon. USDA Forest Service. Research Paper PNW-202. Corvallis, OR.

Ellies, A., Ramirez, C., MacDonald, R. 2005. Organic matter and wetting capacity distribution in aggregates of Chilean Soils. Catena 59, 69-78.

Erickson, H.E., White, R. 2008. Soils under fire: soil research and the Joint Fire Science Program. USDA Forest Service. General Technical Report PNW-GTR-759. Portland, OR. $17 \mathrm{p}$.

Gilmour, D.A. 1968. Water repellence of soils related to surface dryness. Austral. For. 32, 145148.

Huffman, E.L., MacDonald, L.H., Stednick, J. D. 2001. Strength and persistence of fire-induced soil hydrophobicity under ponderosa and lodgepole pine, Colorado Front Range. Hydrol. Process. 15, 2877-2892.

Huber, A., Iroume, A., Bathurst, J. 2008. Effect of Pinus radiata plantations on water balance in Chile. Hydrol. Process. 22, 142-148.

John, P.H. 1978. Heat-induced water repellency in some New Zealand pumice soils. New Zeal. J. Sci. 21, 401-407.

Karnok, K.J., Rowland, E.J., Tan, K.H. 1993. High pH treatment and the alleviation of soil hydrophobicity on golf greens. Agron. J. 85, 983986.

King, P.M. 1981. Comparison of methods for measuring severity of water repellence of sandy soils and assessment of some factors that affect its measurement. Aust. J. Soil Res. 19, 275-285.

Letey, J., Welch, N., Pelishek, R. E., Osborn, J. 1962. Effect of wetting agents on irrigation of water repellent soils. Calif. Agr. 16 (12), 12-13.

Letey, J., Carrillo, M.L.K., Pang, X.P. 2000. Approaches to characterize the degree of water repellency. J. Hydrol. 231-232, 61-65

Leighton-Boyce, G., Doerr, S.H., Shakesby, R. A., Walsh, R.P.D. 2007. Quantifying the impact of soil water repellency on overland flow generation and erosion: a new approach using rainfall simulation and wetting agent on in situ soil. Hydrol. Process. 21, 2337-2345. 
McGhie, D.A., Posner, A.A. 1980. Water repellence of a heavy-textured Western Australian surface soil. Aust. J. Soil Res. 18, 309323.

Neary, D.G. 2009. Post-wildland fire desertification: Can rehabilitation treatments make a difference? Fire Ecol. 5, 129-144.

Paskoff, R. 1996. Atlas de las Formas de Relieve de Chile. Instituto Geográfico Militar. Santiago. $288 \mathrm{p}$.

Robichaud, P.R., Beyers, J.L., Neary, D.G. 2000. Evaluating the effectiveness of post-fire rehabilitation treatments. USDA Forest Service General Technical Report RMRS-GTR-63. Fort Collins, CO. 85 p.

Romero, H. 1985. Geografía de los Climas. Geografía de Chile, Tomo XI. Instituto Geográfico Militar, 243 p.

Scott, D.F. 1997. The contrasting effects of wildfire and clearfilling on the hydrology of a small catchment. Hydrol. Process. 11, 543-555.

Scott, D.F., Van Wyk, D.B. 1990. The effects of wildfire on soil wettability and hydrological behavior of an afforested catchment. J. Hydrol. 121, 239-256.
Stropki, C.L., Ffolliott, P.F., DeBano, L.F. Neary, D.G. 2005. Water-repellent soils on the Stermer Ridge Watersheds after the RodeoChediski Wildfire: a preliminary assessment. Hydrol. Water Resour. Arizona SW 35, 47-50.

Wallis, M.G., Scotter, D.R., Horne, D.J. 1991. An evaluation of the intrinsic sorptivity water repellent index on a range of New Zealand soils: Aust. J. Soil Res. 29, 353-362.

Wohlgemuth, P.M., Robichaud, P.R. 2007. The effects of selected post-fire emergency rehabilitation techniques on small watershed sediment yields in southern California. In: Furniss, M., Clifton, C., Ronnenberg, K. (eds.). 2007. Advancingthe Fundamental Sciences: Proceedings of the Forest Service National Earth Sciences Conference, San Diego, CA, 18-22 October 2004, PNWGTR-689, Portland, OR: U.S. Department of Agriculture, Forest Service, Pacific Northwest Research Station. 